\title{
Role of UASBs in River Water Quality Conservation in India
}

\author{
Veeresh Gali ${ }^{1 *}$, Manisha Thakur ${ }^{2}$, Ashok Kumar Gupta ${ }^{1}$, and Rajiv Ganguly ${ }^{1}$ \\ ${ }^{1}$ JUIT Waknaghat, Civil Department, Teh. Kandaghat, Dist. Solan,173234 H.P, India \\ ${ }^{2}$ Chandigarh Group of Colleges Jhanjeri, Civil Department, Dist. Mohali, Punjab, India
}

\begin{abstract}
Appropriate low-cost treatment technologies are a prerequisite for sound management of natural water resources against pollution in developing countries. Among the existing technologies available, UASB is found to be economically viable for India when considering all factors including operation and maintenance cost and treatment efficiency. However, this technology suffers setbacks in meeting the effluent guidelines prescribed by the government of India. Post treatment is supplemental to this process to meet the effluent standards in terms of removal of organic matter, suspended solids, pathogens and nutrients. Recent stringent effluent guidelines notified by the Ministry of Environment, Forests and Climate Change, Government of India has further reduced the limits of BOD by 3 times, COD and TSS by 5 times, NH4-N and total Nitrogen by 10 times as compared to the previous guidelines. $\mathrm{Fe}_{\text {cal }}$ Coliforms has been specified as $<100 \mathrm{MPN} / 100 \mathrm{~mL}$. In this paper, the present scenario of UASB based STPs and their role in river conservation is reviewed against the backdrop of stringent effluent guidelines. The minimum removal rates of BOD, COD and TSS in these plants are around $42-44 \%$ and the average removal rates are reported to be $66 \%, 61 \%$ and $65 \%$ respectively. The enhanced removal of BOD (97\%), COD (98\%) and TSS has been reported in STPs in conjunction with post treatment facilities such as facultative aerated lagoons, aeration tanks and polishing ponds.
\end{abstract}

\section{Introduction}

India is the second most populous country in the world with an estimated population of over 1.3 billion during 2017. There are 29 states and 7 Union Territories(UTs) in the country. Central Pollution Control Board (CPCB), is an apex body under the Ministry of Environment, Forest and Climate Change (MOEF \& CC), Government of India (GOI) for control and abatement of pollution in India. According to $\mathrm{CPCB}$, the estimated sewage generation in the country during 2015 was 61,948Million Litres per Day (MLD) against available treatment capacity of 23,277 MLD. There are 816 Sewage Treatment Plants (STPs) in the country out of which 522 are operational, 79 are non-operational, 145 are under construction and 70 are under planning stage. While the existing installed treatment capacity corresponds to around $37.6 \%$, the operational capacity of the STPs is only $30.5 \%$

\footnotetext{
* Corresponding author: veeresh_ghali@yahoo.com
} 
of the total sewage generated. The remaining untreated sewage is discharged into nearby water bodies. Domestic sewage is considered responsible for about $80 \%$ of the water pollution in India due to inadequate sewage treatment facilities. The National River Conservation Directorate (NRCD) which functions under MOEF \& CC provides assistance to various State Governments for implementing the River Action Plans in 29 identified grossly polluted stretches of various rivers of India under the National River Conservation Plan (NRCP). The objective of NRCP is to improve the water quality of these rivers, which are the major fresh water sources in the country, through the implementation of pollution abatement schemes. MOEF \& CC in its draft notification released on 24 November 2015 under the Environment (Protection) Act, 1986 has set up new standards for sewage treatment plants along with time frame for implementation as shown in Table 1. Achievement of standards for existing STPs is within 05 years from date of notification.

Table 1. Standards for Sewage Treatment Plants.

\begin{tabular}{|l|l|l|}
\hline Parameters & Standards for New STPs & Existing general effluent standards \\
\hline $\mathrm{pH}$ & $6.5-9.0$ & $5.5-9.0$ \\
\hline BOD & 10 & 30 \\
\hline COD & 50 & 250 \\
\hline TSS & 20 & 100 \\
\hline NH4-N & 5 & 50 \\
\hline N-Total & 10 & 100 \\
\hline $\begin{array}{l}\text { Fecal Coliforms } \\
(\text { MPN/100mL) }\end{array}$ & $<100$ & Not specified earlier \\
\hline
\end{tabular}

Note:

(i) All values in $\mathrm{mg} / \mathrm{L}$ except $\mathrm{pH}$ and Coliform.

(ii) These standards will be applicable for discharge in water resources as well as for land disposal. The

standards for $\mathrm{Fe}_{\mathrm{Cal}}$ Coliform may not be applied for use of treated sewage in industrial purposes.

\section{Overview of Sewage Generation in India}

There are 53 urban agglomerations in India with a population of 1 million or more as of 2011 against 35 in 2001. The rapid rate of growth of urbanization from 10.7\% in 1971 to $37.7 \%$ in 2011 has put lot of stress on urban infrastructure including potable water supply and safe disposal of wastewater. According to CPCB report on inventorization of STPs in India published in March 2015, the states/UTs generating various amounts of sewage are shown in Fig. 1.

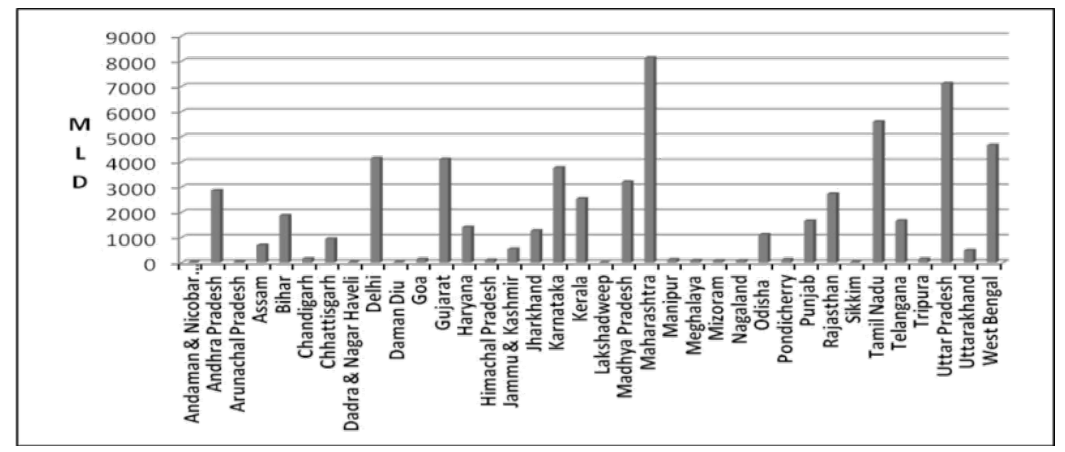

Fig. 1. Sewage Generation of Urban Population in 2015 (calculated @ 148 Lpcd) [5]. 
There are three states which contribute to more than 5000MLD of sewage whereas Lakshadweep is a UT contributing to $10 \mathrm{MLD}$ as shown in Table 2. The five states i.e., Maharashtra (13\%), Gujarat (7\%), Uttar Pradesh (12\%), Delhi (7\%) and Tamil Nadu (9\%) contributed to around $50 \%$ of the sewage generated in India whereas $67 \%$ of the total sewage treatment capacity is installed in these states/UTs.

Table 2. Sewage Generation Classification.

\begin{tabular}{|l|c|l|}
\hline $\begin{array}{c}\text { Sewage Generation, } \\
\text { MLD }\end{array}$ & $\begin{array}{c}\text { No. of } \\
\text { States/UTs }\end{array}$ & \multicolumn{1}{|c|}{ State/UT } \\
\hline Less than 10 & 1 & $\begin{array}{l}\text { Lakshadweep, Andaman \& Nicobar Islands, Arunachal } \\
\text { Pradesh, Dadra }\end{array}$ \\
\hline 10 to 50 & 5 & and Nagar Haveli, Daman Diu and Sikkim \\
\hline $50-100$ & 3 & Meghalaya, Mizoram and Nagaland \\
\hline $100-500$ & 7 & $\begin{array}{l}\text { Chandigarh, Goa, Himachal Pradesh, Manipur, } \\
\text { Pondicherry, Tripura and Uttarakhand }\end{array}$ \\
\hline $500-1000$ & 3 & Assam, Chhattisgarh and Jammu \& Kashmir \\
\hline $1000-2000$ & 6 & $\begin{array}{l}\text { Bihar, Haryana, Jharkhand, Odisha, Punjab and } \\
\text { Telangana }\end{array}$ \\
\hline $2000-5000$ & 8 & $\begin{array}{l}\text { Andhra Pradesh, Delhi, Gujarat, Karnataka, Kerala, } \\
\text { Madhya Pradesh, Rajasthan, West Bengal }\end{array}$ \\
\hline$>5000$ & 3 & Maharashtra, Tamil Nadu and Uttar Pradesh \\
\hline Total & & \multicolumn{1}{|c}{36} \\
\hline
\end{tabular}

The overall BOD load discharged into surface water bodies has been assessed as 14352.7 TPD out of which less than 1\% is contributed by industries [6]. The raw sewage characteristics with respect to BOD, COD and TSS are reported to range from $50-$ $250 \mathrm{mg} / \mathrm{L}(185.5 \mathrm{mg} / \mathrm{L}), 100-700 \mathrm{mg} / \mathrm{L}(481 \mathrm{mg} / \mathrm{L})$ and $100-500 \mathrm{mg} / \mathrm{L}(328 \mathrm{mg} / \mathrm{L})$ with average values in parenthesis. Average COD to BOD ratio is found to be around 2.6 [3].

\subsection{Status of Sewage Treatment in India}

During 2015, the installed treatment capacity of STPs was $37.58 \%$ of the total sewage generated by Urban Agglomerations out of which $81.12 \%$ of the sewage was under operational capacity of installed STPs while 5.32\% was non-operational, $10.86 \%$ of the sewage would be treated in STPs under construction and $2.70 \%$ of the sewage was under proposed capacity as shown in Fig. 2.

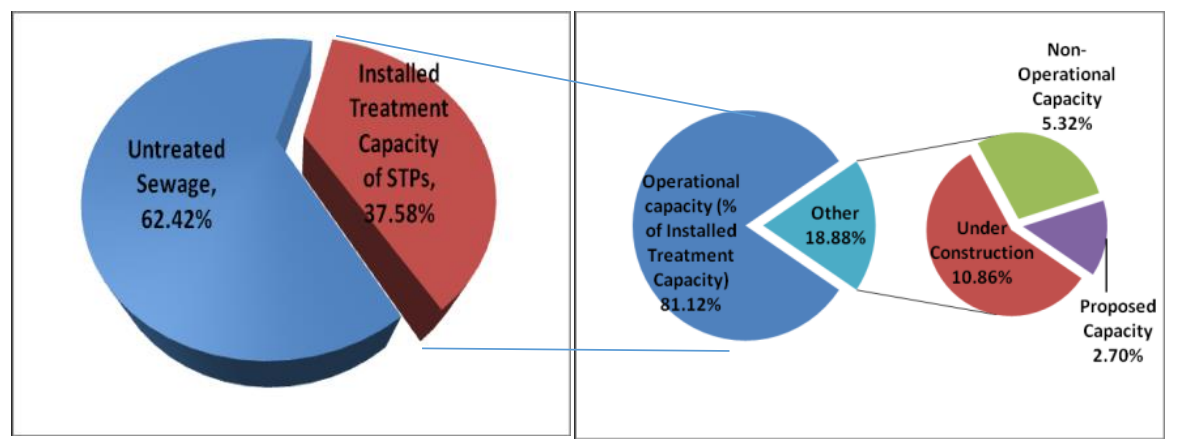

Fig. 2. Sewage treatment potential in India. 
Out of 816 STPs, 522 were in operation whereas 79 STPs were non-operational and 145 STPs were under construction as shown in Fig. 3. The number of STPs proposed are 70 with treatment capacity of 628.64 MLD.

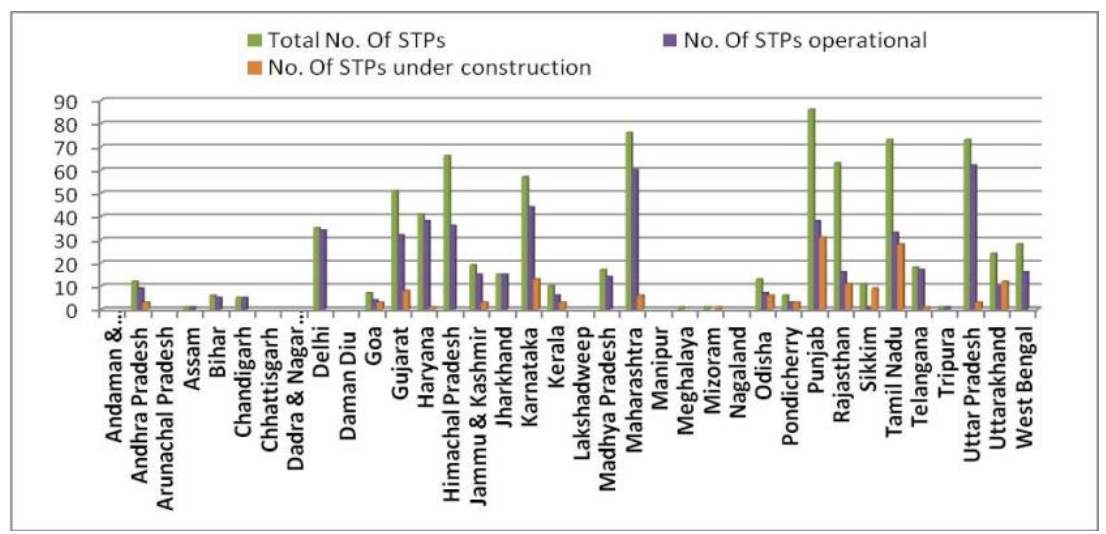

Fig. 3. Status of STPs in India.

There are different technologies which are adopted for the treatment of sewage in India, which includes Activated Sludge Process (ASP), Waste Stabilization Ponds(WSP), Aerated Lagoons (AL), Trickling Filters (TF), Fluidizied Aerated Bed (FAB), Upflow Anaerobic Sludge Blanket (UASB), Oxidation Pond (OP) and advanced technologies like Sequencing Batch Reactor (SBR), Membrane bioreactor (MBR) [5]. The STPs prevailing in India are shown in Fig. 4.

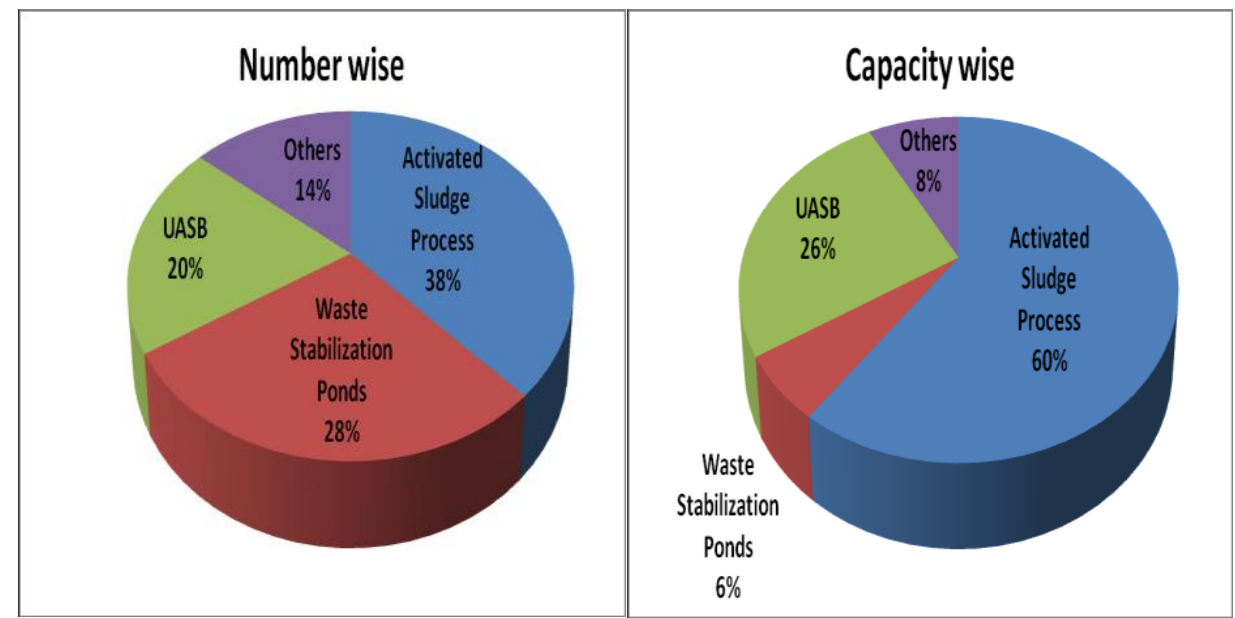

Fig. 4. Status of different types of sewage treatment technology in India [1].

In recent years, UASB technology has been extensively employed for treatment of domestic sewage in India. It is claimed that $80 \%$ of total UASB reactors installed globally for domestic wastewater treatment are in India [10]. 48 UASB based STPs are in operation accounting for around $72 \%$ of the plants and remaining are either non-operational or under construction and commissioning phase [5] as shown in Fig. 5. 


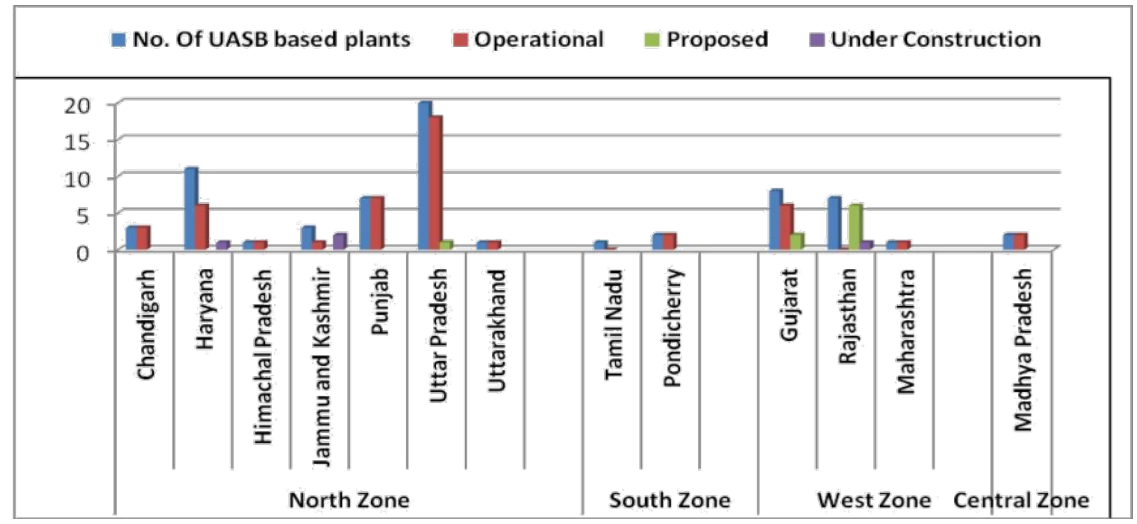

Fig. 5. UASB based STPs in India, Zone-wise [5].

\subsection{Performance of UASB based STPs in India}

The Government of India initiated the Yamuna Action Plan (YAP) in 1993 for conservation of river Yamuna under which 16 UASB STPs were commissioned [10] and 19 UASB plants under Ganga Action Plan-Phase I (GAP-I) [5]. The average BOD, COD and TSS removal efficiency of UASB based plants in India is reported to be $66 \%, 61 \%$ and $65 \%$ respectively. The maximum BOD and COD removal efficiency has been found in UASB based STPs in Hyderabad. 97\% BOD removal efficiency is reported from 30MLD Nallacheruvu plant with $9 \mathrm{hrs}$ HRT in UASB reactor followed by 1 day HRT in facultative aerated lagoons. Similarly, 98\% COD reduction is obtained in 339 MLD STP in Amberpet, Hyderabad. The HRT of UASB reactor is $8.88 \mathrm{hrs}$ and that of Aeration tanks and Polishing Ponds are 1day and $12 \mathrm{hrs}$ respectively. Minimum BOD removal efficiency of $44 \%$ is reported from 14MLD STP in Jaganpur, Agra with UASB technology followed by Polishing Ponds for post treatment whereas 56MLD STP in Ghaziabad has a minimum COD removal efficiency of $42 \%$. The designed capacity of this plant is 56 MLD whereas actual treatment capacity is 58 MLD [4]. HRT of UASB is $10.7 \mathrm{hr}$ and that of Final Polishing Unit is 1.5 day [13]. The average TSS removal efficiency of UASB reactors treating sewage is $65 \%$. Maximum removal efficiency is found in 78 MLD STP in Kabt Khedi, Indore, Madhya Pradesh and minimum TSS removal efficiency is of 40 MLD STP in Karnal which is about $42 \%$. UASB alone does not meet discharge standards; therefore, various post-treatments were used in combination with UASB reactor to achieve desired BOD and SS reduction [10]. The best operating full scale UASB reactor has achieved 67, 70 and $75 \%$ of removal efficiencies for COD, BOD and TSS in which temperature varies between 17 and $27^{\circ} \mathrm{C}[15]$.

\section{State of Art Post-Treatment}

The prime objective of installing post-treatment in combination with UASB reactor is to meet the effluent standards set by NRCD for public health, safety, water usage and environmental considerations [13]. There are various types of post-treatment configurations based on different combinations such as UASB + Activated Sludge, UASB + Biofilm Aerobic Reactor System, UASB + Polishing Ponds etc. UASB with ASP is considered most appropriate combination for treatment in warm conditions than the conventional AS system alone [11]. Polishing ponds are very interesting alternative post-treatment option because they require less investment costs and simple design and operation [13]. Utilization 
of UASB reactor and polishing ponds can reduce the problems related to odours in plants [2]. Polishing pond technology has been used commonly in many developing countries because the polishing pond effluent can be used for agriculture purposes as it aims at the removal of pathogens present in sewage [7]. UASB/SAB can maintain stable operational conditions without being affected by influent load variations [7]. TF can be adopted as post-treatment for treating UASB effluent for low hydraulic and organic rates under mesophilic conditions in tropical countries [11].

\section{UASB Operations and Maintenance}

The overall efficiency of STPs depends on the operation and maintenance of reactor. The UASB technology should be constructed, operated and maintained by professionals. UASB reactor operation requires various activities which are necessary for better performance of a reactor. Activities like process performance monitoring, collection of data, collection of influent and effluent samples for testing, collection of sludge samples, etc. Operator of the plant is fully responsible for the operation and maintenance of plant and a skilled and experienced operator is required to monitor the reactor and repair the part. Plant operation also includes start-up process and shut down of the plant. UASB plant requires a long startup period as it takes several months for sludge to form and to adapt to the characteristics of the wastewater. During starting phase, the granulation process accelerates by high organic loading rates in connection with lower organic loading rates [14]. Monitoring of sludge and its profile inside the reactor is one of the major operational activities related to UASB plants [10]. Maintenance of UASB plant includes removal of floating layers inside the gas dome at least once in six months, cleaning and repairing of gutters, V- notch weir plates, baffles and feeding boxes, checking of the level of the overflow weirs yearly, removal of floating scum/material at the top of the water surface of the reactor once a day and cleaning of chocked feeding pipes [12]. Consequences of operational failure include deterioration of effluent quality [8] and impose a barrier for energy recovery by blocking the natural passage of gas [9]. Operation and maintenance cost of UASB plants is less than $1 \%$ of the capital cost per annum [10].

\section{Conclusions}

It is observed that all UASB based STPs are not capable of producing effluent that follows the discharge standards in terms of BOD, COD and TSS removal. Minimum removal rates of BOD, COD and TSS of $42-44 \%$ have been found in some plants despite of having post treatment technologies. This may be because of poor operation and maintenance of STPs such as improper cleaning of screens at inlet and ponds, excess sludge accumulation in reactors and ponds and hiring of persons with less knowledge of plant operations.

The underperformance of UASB based STPs in achieving the regulatory standards set forth by the MOEF \& $\mathrm{CC}$ has been attributed to some of the following reasons by various researchers and reports:

- Actual Capacity of the plants exceeds the Design Capacity which would affect the HLR and HRT of the reactors.

- Mixing of Industrial Wastewater along with sewage affects the influent characteristics and design flow for which the STPs are designed. In turn, the STPs may be subjected to shock organic and hydraulic loading. The toxic and inhibitory compounds present in industrial wastewater can affect the biological processes.

- Leakage of raising mains/pipelines. 
Improper operation and Maintenance involves non-functioning of bar screens, pumps, flow measuring devices, Diesel Generator (DG) sets during power failure, gas collection system etc.

\section{Recommendations based on Literature, Reports and personal opinion}

- The estimation of sewage generation is based on $80 \%$ of the fresh water supplied by the Urban Local Bodies (ULBs) / Municipal Corporation (MC). However, the discharge may vary given the individual household supplies through private wells and other sources.

- The performance evaluation of UASB based STPs are made on grab sampling done one time. However, data based on composite sampling would be more realistic. Studies may be carried out under different seasons

- Need for trained and experienced workers to analyse the treatment performance at defined time intervals

- UASBs are vulnerable to shock loads, shock temperature, organic loading rate, hydraulic loading rate etc. Equalization tanks may be installed to overcome such shock loads.

- Operational guidelines should be strictly followed

- Periodic Sludge Profiling of UASB reactor as a Sludge Management tool can enhance UASB performance

- Upgradation of STP facilities and physical improvement of FPUs by adding an aerator and extending retention time or re-evaluation of FPUs by considering alternate technologies such as ASP, TF and RBC. UASB with ASP is considered the most suitable combination as it can achieve $85-95 \%$ removal rates

- Consideration of Down Hanging Sponge System (DHS) as a novel technology in post treatment

- $\quad$ Since the STPs vary in both size and effluent quality, a parameter such as Effluent Quality Index (EQI) may be generated to evaluate the STPs on a common platform.

To optimize the performance of STPs, the UASB reactors should be maintained and operated properly. Maximum removal rates are found in some plants which are in combination with post treatment facilities such as facultative aerated lagoons, aeration tanks and polishing ponds. While most of the STPs are evaluated for previous discharge standards, they should be re-evaluated for current standards and necessary measures be taken.

\section{References}

1. A. Majumder, [online] Available: http://www.cseindia.org/userfiles/arunabha.pdf

2. P. F. F. Cavalcanti, A.Van Haandel, G. Lettinga, Water Sci. and Technol 44 (4), 237245 (2001)

3. Central Pollution Control Board(CPCB), [Online] Available: http://cpcb.nic.in/newitems/12.pdf (2005, November)

4. Central Pollution Control Board(CPCB) (Ministry of Environment and Forests, Govt. of India), [online] Available: http://cpcb.nic.in/upload/NewItems/NewItem_195_STP_REPORT.pdf (2013)

5. Central Pollution Control Board(CPCB) (Ministry of Environment and Forests, Govt. of India)

[online] 
Available:http://nrcd.nic.in/writereaddata/FileUpload/NewItem_210_Inventorization_o f_Sewage-Treatment_Plant.pdf(2015,March)

6. Central Pollution Control Board(CPCB), Bulletin, 1 [online], Available: http://cpcb.nic.in/upload/Latest/Latest_123_SUMMARY_BOOK_FS.pdf (2016, July)

7. C. D. L. Chernicharo, Reviews in Environ. Sci. and Bio/Technol 5 (1), 73-92 (2006)

8. C. D. L. Chernicharo, P.G.S. Almeida, Sustainable Solutions for Small Water and Wastewater Treatment Systems, Spain, (2010)

9. C. D. L. Chernicharo, J. B. van Lier, A. Noyola, T.B. Ribeiro, Reviews in Environ. Sci. and Bio/Technol 14 (4), 649-679 (2015)

10. N. Khalil, R. Sinha, A.K. Raghav,A.K. Mittal, IWTC 12, 1411-1427 (2008)

11. A. A. Khan, R. Z. Gaur, V. K. Tayagi, A. Kursheed, B. Lew, I. Mehrotra, A. A. Kazmi, Resources, Conservation and Recycling 55, 1232-1251 (2011)

12. Operation and Maintenance Manual for 19.35MLD Sewage Treatment Plant at Lalpani, Shimla, MWH India Pvt. Ltd.

13. N. Sato, T. Okubo, T. Onodera, A. Ohashi and H. Harada, J. Envir. Mgmt. 80, 198-207 (2006)

14. L. Sasse, Bremen, Bremen Overseas Reasearch and Development Association (BORDA) (1998)

15. J. B. Van Lier, A. Vashi, J. Van Der Lubbe, B. Heffernan, H. Fang, Anaerobic sewage treatment using $U A S B$ reactors: engineering and operational aspect (Imperial College Press, London, UK, 2010) 